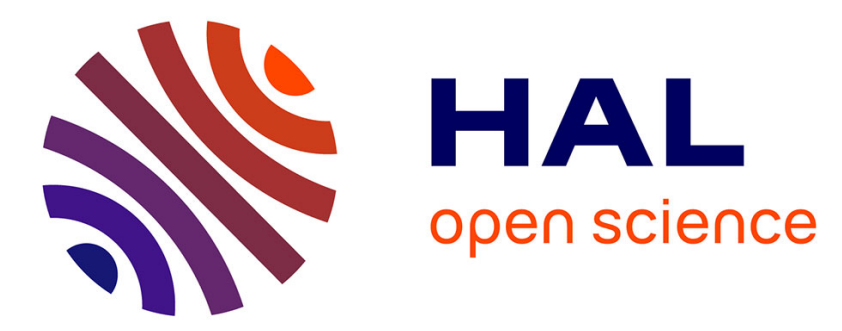

\title{
INFLUENCE OF DOPING ELEMENTS ON THE GRAIN BOUNDARY CHARACTERISTICS IN ALUMINA
}

S. Lartigue, L. Priester

\section{- To cite this version:}

S. Lartigue, L. Priester. INFLUENCE OF DOPING ELEMENTS ON THE GRAIN BOUNDARY CHARACTERISTICS IN ALUMINA. Journal de Physique Colloques, 1988, 49 (C5), pp.C5-451-C5456. 10.1051/jphyscol:1988555 . jpa-00228052

\section{HAL Id: jpa-00228052 https://hal.science/jpa-00228052}

Submitted on 1 Jan 1988

HAL is a multi-disciplinary open access archive for the deposit and dissemination of scientific research documents, whether they are published or not. The documents may come from teaching and research institutions in France or abroad, or from public or private research centers.
L'archive ouverte pluridisciplinaire HAL, est destinée au dépôt et à la diffusion de documents scientifiques de niveau recherche, publiés ou non, émanant des établissements d'enseignement et de recherche français ou étrangers, des laboratoires publics ou privés. 
JOURNAL DE PHYSIQUE

Colloque C5, supplément au $\mathrm{n}^{\circ} 10$, Tome 49, octobre 1988

INFLUENCE OF DOPING ELEMENTS ON THE GRAIN BOUNDARY CHARACTERISTICS IN ALUMINA

\author{
S. LARTIGUE and L. PRIESTER \\ Laboratoire de Métallurgie Structurale,CNRS-UA 1107, Université \\ Paris-Sud, F-91405 Orsay Cedex, France
}

\begin{abstract}
Résumé - La distribution et les caractéristiques des joints de grains ont été déterminées dans une alumine pure et une alumine dopée à la magnésie. L'alumine dopée présente une proportion élevée de joints "spéciaux" de coïncidence tandis que dans l'alumine pure la plupart des joints sont "généraux" mais présentent des plans denses. Les distributions des joints de grains sont analysées en relation avec les microstructures des deux matériaux.

Abstract - The distribution and characteristics of grain boundaries have been determined in pure undoped and $\mathrm{Mg}$-doped aluminas. Mg-doped alumina presents a high proportion of "special" coincidence boundaries while in pure undoped alumina most of boundaries are general but present densely packed planes: The grain boundary distributions are analysed in relation with the microstructures of the two materials.
\end{abstract}

\title{
I - INTRODUCTION
}

Most technologically important properties of polycristalline ceramics, in particular their aptitude for high temperature deformation, are strongly influenced by the grain boundaries. A recent objective is to obtain microstructures with good ductility. For example Mg-doping of polycristalline alumina leads to a fine grained microstructure and good sintering behavior.

This material may undergo large compressive strains at high temperature similarly to the superplastic phenomenon exhibited by some metallic alloys [1]. Deformation occurs by interface controlled diffusion creep, the predominant process being grain boundary sliding [2]. It involves many intergranular properties, such as diffusion and the operating of sources or sinks for dislocations that may depend on the grain boundary characteristics.

In our previous work, we have pointed out a wide difference between "special" and "general" boundaries in their role in creep; we concluded that distribution of grain boundaries in the polycristals would be taken into account to understand deformation at high temperature [3].

In the present paper, we compare the distribution of the grain boundary characteristics in pure undoped alumina and Mg-doped alumina.

II - EXPERIMENTAL PROCEDURE

Our study by Transmission Electron Microscopy is based on a geometrical approach to the coincidence concept that has been first systematized in the hexagonal system by DELAVIGNETTE [4]. Very recently, Tables of coincidence relevant to the rhombohedral system and particularly to alumina have been established by GRIMMER (personal communication). A distinction has to be made between two types of coincidence misorientation relationships: 
- coincidences common to all the hexagonal crystals for any c/a ratio and corresponding to rotations around [0001], named $\Sigma \mathrm{N}_{\text {ex }}$ in the text,

- rational coincidences existing for the rational values of $\frac{\mu}{\nu}\left(\mu / \nu=\left(\frac{c}{a}\right)^{2}\right)$; in the case of alumina $\frac{\mu}{\nu}=\frac{15}{2}$ and $\sqrt{\mu} / \nu=2,739$ close to $\frac{\mathrm{c}}{\mathrm{a}}$ (alumina) $=2,73$.

The experimental deviation from these descriptions is calculated using a geometrical method and compared to a limited theoretical value given by BRANDON [5]. Low Angle, C.S.L.'s (Coincidence Site Lattice) and C.A.D. (Coincidence Axis Direction) boundaries are classified as "special". These boundaries have been found to contain periodic networks of intrinsic (IGBD's) or pseudo-periodic networks of extrinsic (EGBD's) dislocations. The occurrence of these latter networks may constitute an indirecte proof of the boundaries' speciality [6].

CAD boundaries present a periodicity along one dimension only, the deviation from the coincidence being accommodated by dislocations of which the BURGERS vector must be a $\vec{b}_{3}$ vector of D.S.C. lattice. In alumina CAD boundaries correspond either to a relatively good matching of densely packed planes (1123) or (0112) of the two crystals or to a misorientation around low indexed rotation axes such as $\langle 1120\rangle,\langle\overline{1} 011\rangle$, $\langle 12 \overline{3} 1\rangle$, and $\langle 10 \overline{1} 2\rangle$, which are parallel to possible BURGERS vectors of a perfect lattice dislocation [7]. (the largest allowed deviation between two parallel planes or axes has been fixed to $\Delta \theta=2^{\circ}$ )

In the present work, another type of special boundaries, called near coincidence boundaries, related to a particular position of the boundary plane, was found and will be described in paragraphe III-2.

III - RESULTS AND DISCUSSION

III - 1 - MICROSTRUCTURE AND DISTRIBUTION OF GRAIN BOUNDARIES

The sintered materials have been obtained by vacuum hot pressing at $1500^{\circ} \mathrm{C}$ under a pressure of $40 \mathrm{MPa}$. The starting material was either a pure powder $(99,96 \%)$ containing low quantities of potassium*, or powder doped with $500 \mathrm{ppm}$ of $\mathrm{Mg}-0$ by weigt. Both samples contain $\beta^{\text {: }}$ plate-like precipitates with a high $K$ content, located at triple junctions.

In the Mg doped alumina, grains are mostly equiaxed with a mean grain size of about 0,5 to $1 \mu \mathrm{m}$; small intergranular voids associated to dislocations may be observed (fig.1a). Some of the largest grains display subgrain boundaries and the smallest ones contain dislocation arrays.

In the undoped alumina, the grain size varies from 10 to $50 \mu m$ and some grains have undergone an exaggerated growth with a lengthening along a direction perpendicular to the compression axis ( $\mathrm{fig} . \mathrm{ib}$ )

To analyse the distribution and the characteristics of the grain boundaries, several thin foils were examined and the boundaries have been selected randomly.

In the $\mathrm{Mg}$-doped alumina, nearly half of the thirty boundaries studied are special ( $f$ ig.2a) ; we can assess this proportion is important from a statistical point of view on the basis of the WARRINGTON calculations $[8,9]$ and from experiments that reveal high proportions of special boundaries only in pure materials [6].

Faceting is absent, the boundary planes are always general (fig.2b) as suggested by their usual curved profile. Some special boundaries contain periodic or pseudo-perio dic networks of dislocations, and often surround small grains in agreement with their low mobility(fig. 3a).

In the undoped alumina, among fifty boundaries analysed, only 5 boundaries are special (fig. 2a); howhever half of them possess a plane parallel to densely packed planes, most often the (0001) basal plane, at least in one grain (fig. $2 b$ ).

In particular this is the case of the elongated grains for which two important

* C. CARRY, from "Ecole Polytechnique Fédérale, Lausanne", is acknowledged for the preparation of the materials. 
features must be pointed out (fig. 1b):

i) both boundary planes along the direction of lengthening are (0001) planes in the grains,

ii) the [0001] $c$-axis is almost perpendicular to the compression axis.

Another remark concerns the short grain boundaries limiting the elongation of these grains which are either special or possess a special plane in the other grain

(fig. 1b). In this case, they may be faceted, the facets being alternatively parallel to the (0001) planes of the two grains (fig. 3b).

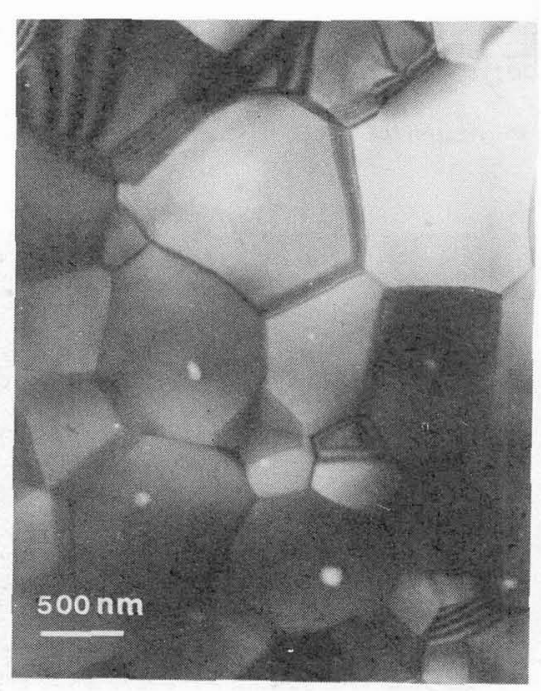

Eigure 1 (a):Bright field image of the microstructure of the Mgdoped alumina. Arrow indicates small void associated to transgranular dislocation.

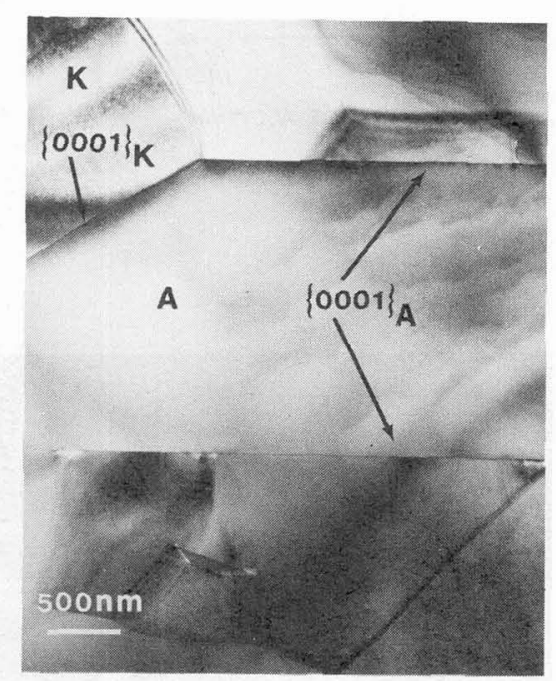

(b): Bright field image of the microstructure of the pure alumina. Straight boundary planes are // (0001) in the large grain. The boundary A/Khas a plane // to (0001) in grain $k$.
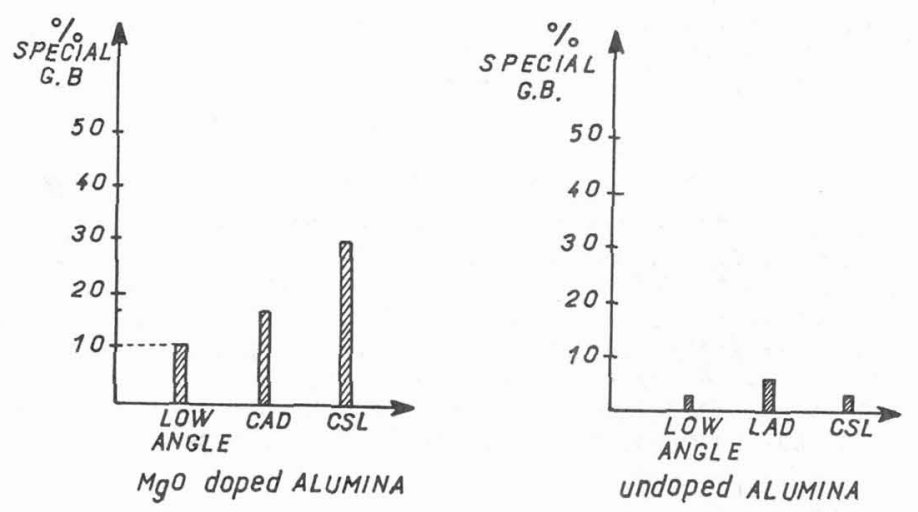

Figure 2(a): Distribution of special grain boundary misorientations in $\mathrm{Mg}$-doped and undoped aluminas. 


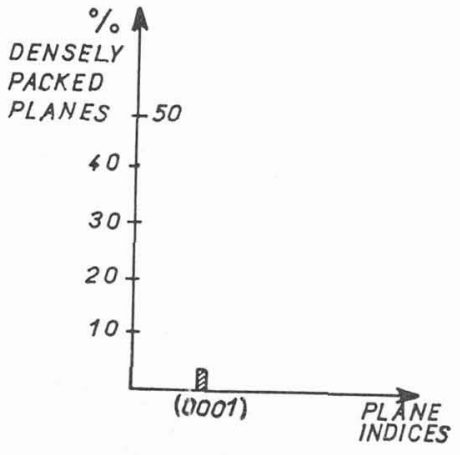

Mg doped ALUMINA

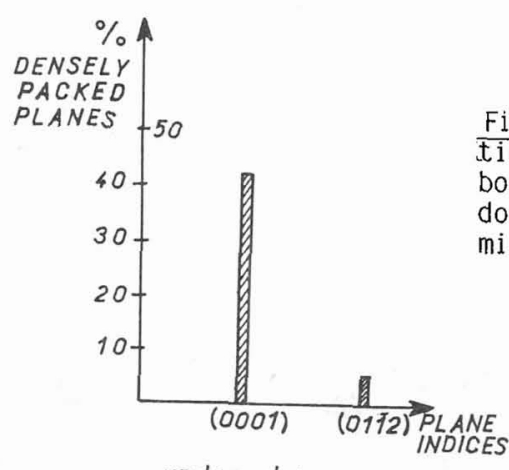

undoped ALUMINA
Figure 2(b): Distribution of special grain boundary planes in $\mathrm{Mg}$ doped and undoped aluminas.

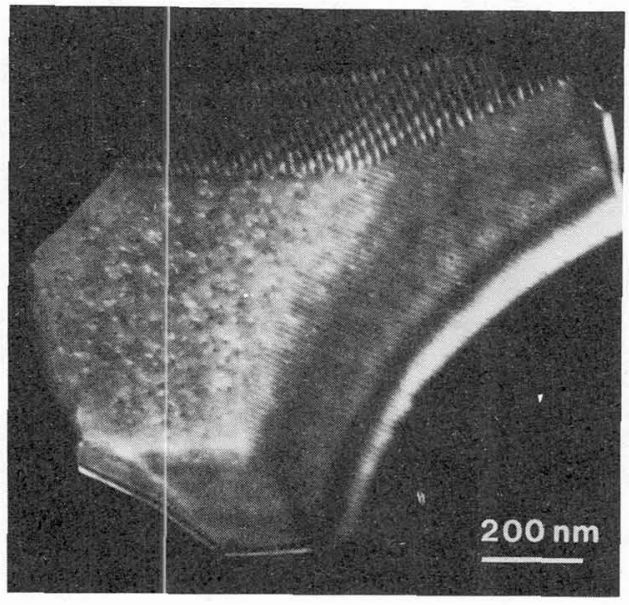

Figure 3(a):Dark field image of a small grain in Mg-doped alumina. 3 boundaries present dislocation networks.

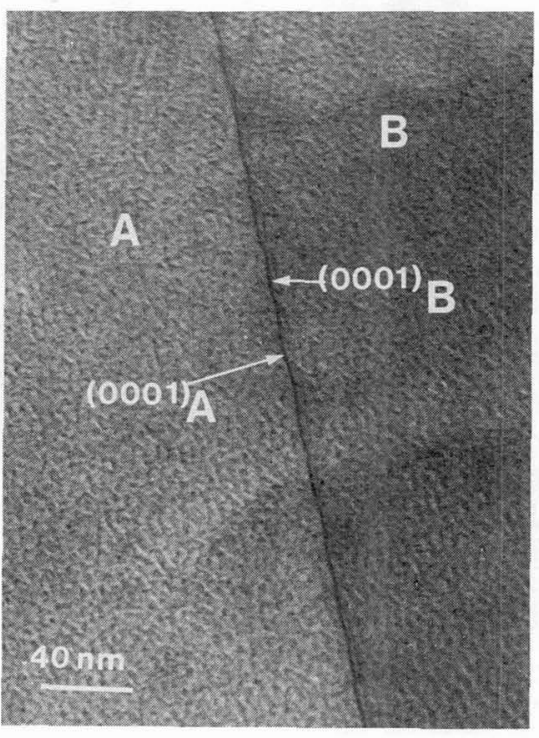

(b): Bright field image of a pure alumina grain boundary. The facets are alternatively // to (0001) plane of the two grains.

III - 2 - SPECIAL NEAR-COINCIDENCE BOUNDARIES IN PURE UNDOPEO ALUMINA

In pure alumina, two grain boundaries contain a dislocation network although they do not correspond to a CSL or a CAD misorientation. We analysed them in terms of nearcoincidence boundaries (N.C.); this situation is encountered when there are commensurate two dimensional nets in the interface or when a two-dimensional CSL is generated in the boundary plane [10]. It is similar to the case of interphase boundaries where a linear misfit, occurring between the two dimensional nets, may be taken up by a VAN DER MERWE dislocation array. This description has been theoretically considered and it has been suggested that such boundaries could be relatively more important in non-cubic crystals:

Apossible analysis is given in the case of a general boundary 1/6(misorientation $172^{\circ}\left[\begin{array}{lll}9 & \overline{8} & 1\end{array}\right]$ ) that presents a boundary parallel to $(0001)$ and $(10 \overline{1})$ dense planes 
in the two crystals. (fig. 4a). A two-dimensional coincidence lattice may be defined in the boundary plane (fig. 4b) with $\sigma_{1}=87$ and $\sigma_{6}=26$. ( $\sigma$ is a coincidenceindex in the boundary plane).

i) The vectors of the parallel directions $\vec{u}_{1}$ and $\vec{u}_{6}$ are:

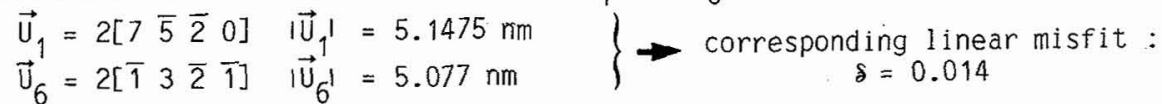

ii) The vectors of the parallel directions $\vec{U}_{1}^{\prime}$ and $\vec{U}_{6}^{\prime}$ are:

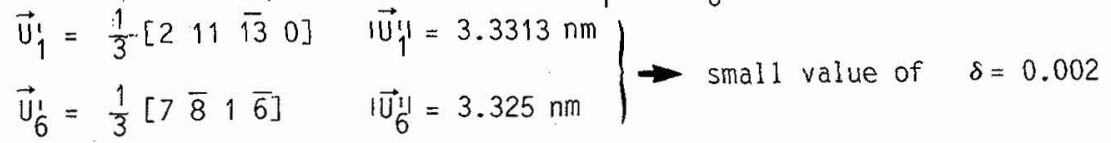

A second near-coincidence cell which presents a less good matching than the first one, may be defined by the unit vectors $\vec{V}$ and $\vec{V}^{\prime}$ with $\sigma_{1}=39$ and $\sigma_{2}=12$.

In this case, the vectors are low indices ones:
i) $\begin{aligned} \vec{v}_{1} & =\left[\begin{array}{llll}4 & \overline{1} & \overline{3} & 0\end{array}\right] \\ \vec{v}_{6} & =2\left[\begin{array}{llll}0 & 1 & \overline{1} & 1\end{array}\right]\end{aligned}$
$\left|\vec{V}_{1}\right|=2.972 \mathrm{~nm}$
$\left|\vec{V}_{6}\right|=2.767 \mathrm{~nm}$

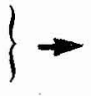
$\delta=0.069$

$$
\begin{array}{ll}
\vec{V}_{1}^{\prime}=\left[\begin{array}{llll}
3 & \overline{4} & 1 & 0
\end{array}\right] & \left|\vec{V}_{\mid}^{\prime}\right|=2.972 \mathrm{~nm} \\
\vec{V}_{6}^{\prime}=2\left[\begin{array}{llll}
\overline{1} & 2 & \overline{1} & 0
\end{array}\right] & \left|\vec{V}_{6}^{\prime}\right|=2.8554 \mathrm{~nm}
\end{array}
$$

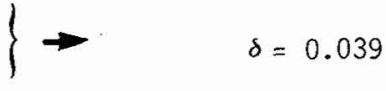

The dislocation's BURGERS vector could not have been determined as their contrast is very weak. The dislocation lines are parallel to $U_{1}$ and $U_{6}$, and the distance between them is $35 \pm 5 \mathrm{~nm}$. They hardly accommodate the linear mis it in the boundary plane as the theoretical distance $D=b / \delta$ does never correspond to $35 \mathrm{~nm}$.

They may result from the small deviation $\alpha$ from the parallelism of (0001) and (1011) planes $\left(\alpha=1^{\circ} \pm 0.5\right)$; if $b=1 / 3[0001], 17<D<50 \mathrm{~nm}$ which is consistent with the experimental distance.
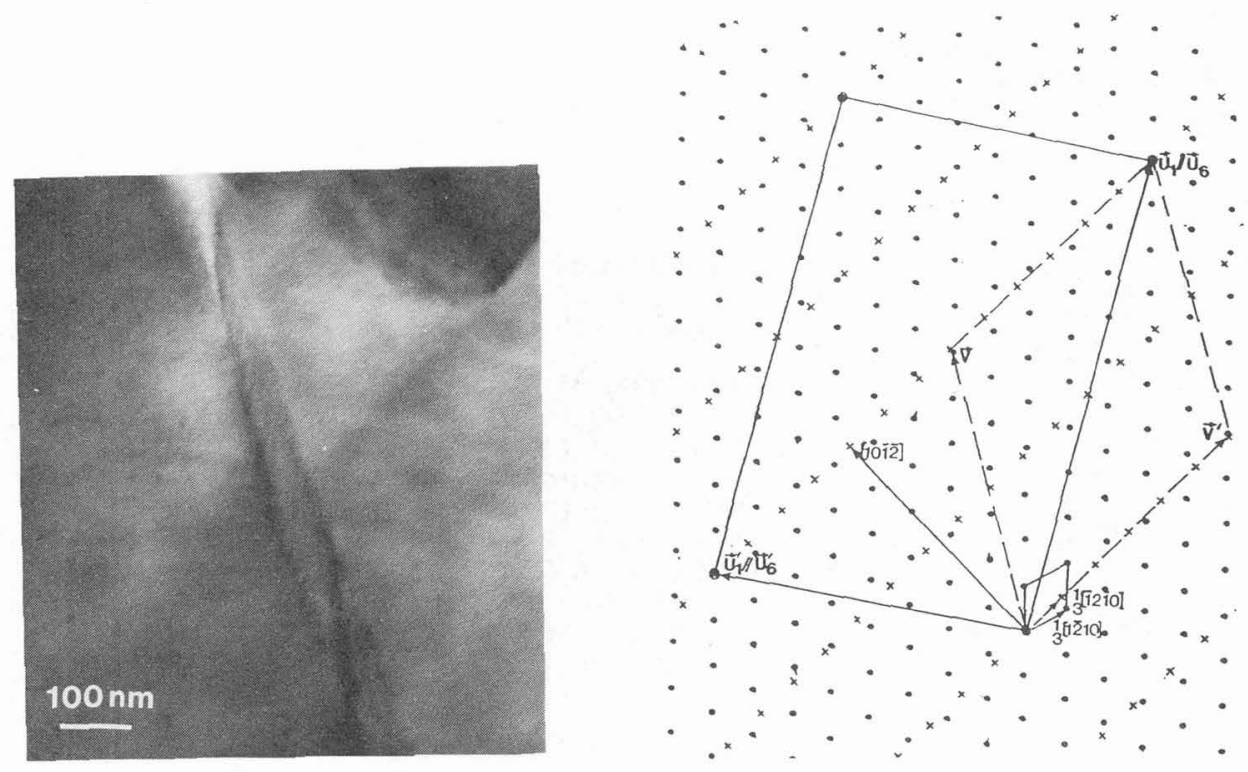

Ficure 4(a):Bright field image of a "general" boundary $1 / 6$. Occurrence of a dislocation network. (b) Near-coincidence cell in the plane of the boundary $1 / 6$ 
Two linked conclusions may be underlined: Special boundaries that are not taken into account by coincidence models may exist in alumina; special boundaries in pure undoped alumina are associated with a particular position of the boundary plane.

\section{III . 3 - DISCUSSION}

The limitation of grain growth by Mg-doping results in a nearly equiaxed ultra fine grained microstructure, which appears to be associated with a high proportion of special boundaries. In pure alumina an exaggerated growth of some grains occurs and most boundaries are general. These remarks suggest that there is a relation between the distributions of grain sizes and grain boundary types.

our results may be compared to the GRABSKI observations on pure aluminium where the fraction of special boundaries was found to depend on the annealing temperature: A low temperature involves a fine grained structure with a high proportion of special boundaries of low mobility, a high temperature leads to a decrease in activation energy for grain growth and special boundaries are eliminated by more mobile general boundaries [11:]. Furthermore clusters of Mg0 were produced by burning magnesium and the distribution of grain boundaries between small crystalline ceramic particles ( $D$ \# $100 \mathrm{~nm}$ ) showed a marked preference for high density CSL's orientation [12].

our results confirm that homogeneous and fine grained microstructure is associated with a high proportion of special boundaries.

Concerning the grain growth in pure alumina, we can state that a selective growth occurs for the grains with a preferred crystallographic orientation relatively to the compressive axis, the direction of the migration being perpendicular to the caxis. This happens with a selection of densely packed planes (basal plane) and a pos. sible mecanism could be the movement of a less dense, very mobile facet along the grain boundary plane, as it was observed by MORRISSEY and CARTER in large-grains commercial aluminas [13].

IV - CONCLUSION

Magnesium strongly modifies both the microstructures and the grain boundary types in alumina : different types of "special" boundaries have been found in the two samples. In the Mg-doped alumina nearly half grain boundaries present special coincidence orientation relationships, while the pure alumina contains a lot of "general boundaries with special boundary plane orientations. These results have been related to the microstructure characteristics.

As special and general grain boundary behaviour are quite different, the knowledge of the grain boundary distribution in a polycristal is important for the understanding of polycrystals properties.

\section{REFERENCES}

1 - J.D. FRIDEZ,C. CARRY, A. MOCELLIN, Advances in Ceramics, 10 (1985) 720

2 - R.M. CANNON, W.H. RHODES, A.H. HEUER, J. of Cer. SOC. 63 (1980) 46

3 - S. LARTIGUE, L. PRIESTER, proceedings of JIMIS-4, Transactions of the Japan Institute of metals (1986) 205

4 - P.DELAVignetTE, J. de Phys. C6-43 (1982) 1

5 - D.G. BRANDON, Acta Metall. 14 (1966) 1479

6 - S. LARTIGUE, L. PRIESTER, Acta Meta11. 31 (1983) 1809

7 - A.H. HEUER, J. CASTAING, Advances in Ceramics 10 (1984) 238

8 - D.H. WARRINGTON, M. BOON, Acta Metall. 23 (1975) 599

9 - D.H. WARRINGTON, J. de Phys. C4-36 (1975) 87

10- R.W. BALLUFFI, T.Y. TAN, Scripta Metall. 6 (1972) 1033

11- M.W. GRABSKI, J. de Phys. C4-46 (1985) 567

12- P. CHAUDHARI, J.W. MATTHEWS, J. of Appl. Phys. 42-8 (1971) 3063

13- K.J. MORRISSEY, C.B. CARTER, J. of Am. Cer. Soc. 67 (1984) 292 